\title{
THE BURNING BORDER. A comparative study of the problem of Trieste and other territorial issues confronted by ltaly after defeat in the Second World War
}

\begin{abstract}
The article describes why the Trieste issue is the only one of the territorial disputes Italy had with neighbouring countries at the end of the Second World War that still influences Italian public opinion and policy. The first part of the work briefly describes the problem that Italy had with its former colonies, and with France, Austria and Yugoslavia. While the topic is not discussed in detail for the sake of brevity, emphasis has been placed to the mutual impact each of these territorial issues had on the others during the period when the looming Cold War influenced all of them. The second half of the article explains what made the Trieste issue unique and why it still plays an important role in the Italian national consciousness. The article is based on Italian, Croatian and Slovenian historiography and refers, for specific aspects, to documents from the Office of the Marshal of Yugoslavia (Fond 836 - Arhiv Jugoslavije) and the Political Archives of the Ministry of Foreign Affairs of the Republic of Serbia (PA - DAMSP).
\end{abstract}

\section{Introduction}

As a consequence of the armistice in September 1943, Italy was deeply divided as a country in several ways. After the ceasefire, which was at least partly a consequence of the Allied landing in Sicily in July, the Nazis quickly occupied the northern part of the country and established a puppet state there, the so-called Italian Social Republic, nominally still under the Mussolini's control.

The fall of fascism 1943 in July and the armistice in September were clearly motivated by the need to salvage a situation which looked increasingly grim at the level of international relations. The legitimate Italian government then sought to "pay the return ticket", ${ }^{1}$ as Winston Churchill put it, by offering what was left of the Italian army to fight on the side of the Allies. This was made in order to achieve a privileged post-war status among the countries that had been on the

PASTORELLI 2009: 21. 
losing side. At the same time, the first attempts were made in the diplomatic field to obtain the best possible terms at the upcoming peace conference.

Despite the commitment of the first post-fascist Italian governments, the territorial disputes Italy had with three of its neighbours - France, Austria and Yugoslavia - and with its former colonies were addressed on the terms dictated by the countries which led the antifascist coalition: sometimes according to their national interests (which was the case with England and the former colonies in the Horn of Africa), sometimes according to the logic of the looming Cold War.

While territorial disputes were mostly resolved in the late 1940s, the fact that Yugoslavia was part of the Soviet bloc until 1948 did put the fate of Trieste on hold, before the Tito-Stalin split further jeopardized it.

Addressed de jure in 1954 with the London memorandum and de facto in 1975 with the Osimo Accords, the issue of Italy's eastern border rose again to national (and international) relevance in the 1990s and 2000s, and is still perceived as relevant.

\section{French troops at the outskirts of Turin}

Italy first had to deal with France. As that country stood among the ranks of the war's victors, it would recall the "knife stabbed in the back of a man who was already on the ground", ${ }^{2}$ as the French ambassador to Italy described Italy's declaration of war against France in 1940. Even though Charles De Gaulle had declared on 30 June 1944 that "France has no territorial claim to make against Italy: it sees no reason to undermine the integrity of Italian territory", ${ }^{3}$ during the autumn and winter of the same year rumours spread that France was making plans to annex the Aosta Valley and certain other territories on the Italian side of the border. ${ }^{4}$ These rumours were soon followed by reports of French troops massing along the border, but, as Harris points out, "the operational benefits to be derived by holding German divisions in north-west Italy over-rode political objections to the employment of French troops east of the Italian border". ${ }^{5}$ In April 1945, French troops were granted permission to cross up to 20 kilometres into Italian territory by the Supreme Allied Commander of the Mediterranean Forces, General Harold Alexander. Problems arose when it was made clear that these troops had, under the orders of General Doyen, penetrated far deeper, almost reaching Turin's outskirts,

2 The picturesque image of the "backstabbing", which was later used by Roosevelt, became so ingrained that it was used in official compilations of diplomatic documents issued by the French government. Cf. FRANÇOIS-PONCET 2009.

3 RAINERO 2001: 215-232.

4 HARRIS 1957: 317.

5 HARRIS 1957: 318. 
while also taking positions in the Liguria and Aosta Valley. President Truman sent than a personal message to De Gaulle asking for an immediate withdrawal of French forces from the region, or all supplies to the French would otherwise be suspended. As a consequence of such a threat, an agreement was reached on 11 June 1945 stipulating that the French would withdraw to the pre-war border within a month.

In the meantime, the French tried to exploit the local independence movement which emerged as a response to the Fascist attempt to "Italianise" the Aosta Valley, where a French dialect, the patoué valdotèn, is spoken. Local pro-Italian anti-fascist forces managed, however, to eliminate all secessionist influences by various means, including the threat that they would go so far as to ally themselves with what was left of the Fascist armed forces in order to form a front against the French. The situation was ultimately addressed by the arrival of an American occupying force which set up its own rule over the region.

A statute granting the region special autonomy, which was signed by Italian King Umberto I soon after the end of the war on September $7^{\text {th }} 1945$, won the support of the local elite, hence the pro-French fraction quickly lost relevance. French claims over the minor border towns of Briga and Tenda appeared more reasonable ${ }^{6}$ and they were indeed annexed by France as a consequence of the Paris peace treaty in $1947 .{ }^{7}$

\section{Libya and the Horn of Africa}

Italy had four colonies. Libya was occupied by British troops at the beginning of 1943 and then held by them until 1950, when the United Nations recognized its independence.

The remaining three were colonies were in the Horn of Africa. Eritrea was occupied by the English as early as in 1941 and they held it until 1952, when it entered a federal union with Ethiopia. Italian Somaliland (present-day northeastern, central and southern Somalia), was occupied by the British in January/ February 1941 and they remained there until it was returned to Italian rule as a trust territory for a period of ten years, until 1960. The last Italian territory in eastern Africa was Ethiopia, of which its conquest in 1935-1936 was one of a few military successes of Fascist Italy, leading to the proclamation of the Italian Empire. For this reason the British, who occupied it with the support of local guerrilla fighters, treated Ethiopia differently than the pre-war Italian colonies and

$6 \quad$ They were part of the Duchy of Savoy for centuries, but although Napoleon III claimed the rest of the territory in return his assistance in the Italian war of liberation in 1859, he allowed the two towns to remain in Italy, as Italy perceived them as important for strategic reasons.

7 VIGNOLI 2008: 17. 
restored its full sovereignty by restoring the country to Emperor Haile Selassie, who had been living in exile since 1936, in compliance with the Anglo-Ethiopian Agreement of December 1944.

In order to maintain its diplomacy, the Italian interim government decided to retain most of the diplomatic corps of the Fascist era. These were people who still perceived the colonies as a vital tool to maintain the status of regional power. For this reason, a strategy was developed to keep the overseas territories. ${ }^{8}$ Moreover, the issue of Italy's colonies was at the core of Great Britain's post-war planning for obvious strategic reasons, ${ }^{9}$ so the British stance was that former Italian colonies were to be reassigned to the United Nations, except, perhaps, for Tripolitania, which was less of a problem as it was not in the Horn of Africa.

The Paris peace treaty signed in 1947 ratified the British decision that Italy should lose its sovereignty over Ethiopia, while the status of Libya, Eritrea and the Italian Somaliland was deferred to the United Nations, i.e., kept on hold. The Big Four were supposed to reach a unanimous agreement over their fate in a year; and failing that, the issue was to be deferred to the General Assembly of the United Nations.

As it seemed possible to retain some control over its colonies, Italy increased its international pressure on this matter. This was, however, all for naught. The intensification of the Cold War during 1947 increased the strategic importance of northern and eastern Africa. The British perceived Libya's coast as an instrument to maintain a foothold in the Mediterranean Sea and Washington supported British aspirations over this territory as a tool to prevent Soviet influence in the Mediterranean. At the same time, in order to exert some control over the Horn of Africa, the Americans were sympathetic to Ethiopian claims over Eritrea. ${ }^{10}$

After pro-Western political parties won the Italian elections in 1948, the government attempted to increase its chances of success by scrapping the request of a direct rule over its former colonies by changing its approach and instead requesting their formal independence and temporary Italian control in the form of trusteeship. ${ }^{11}$

In any case, when the Council of Deputy Foreign Ministers gathered in Paris in September, the major powers could not reach an agreement. On one hand, the Western powers had different views over the future of Italy's overseas territories.

\footnotetext{
MONZALI 2015: 463.

9 The Foreign Office memorandum drafted in preparation for the peace treaty states that "there could be no question of admitting any longer the pretences of Italy to be a Great Power (...) [while] we had a strategic interest in preventing the return of Italy to the Red Sea." HARRIS 1957: 478-480.

10 MONZALI 2015: 467.

11 MONZALI 2015: 474-475.
} 
On the other, the Soviet Union proposed that Italy be granted trusteeship over all of its former colonies. ${ }^{12}$ Moscow, however, changed its approach in a matter of days. ${ }^{13}$ In a move which has been explained as aimed to appease decolonization movements around the world, the Soviet Union proposed than that all of Italy's former colonies be put under direct UN trusteeship. When this proposal was dismissed by the Western powers, the issued was deferred to the UN General Assembly a year after the peace treaty with Italy entered into force.

As it had become clear that Italy had virtually lost any hope of regaining its former colonies, in a move aimed to put Italy's relations with the Arabic countries in a positive track in the future, Prime Minister De Gasperi released a statement on 31 May 1949 to express agreement over the self-determination of Libya and Eritrea. $^{14}$

On 21 November 1949, the General Assembly of the United Nations decided to grant Libya full independence as of 1 January 1952, while an Italian trustee regime over Somaliland was created for the next ten years. The future of Eritrea stood on hold for another year, until the General Assembly decided that it be unified with Ethiopia.

\section{Alto Adige/Südtirol}

Another area which was disputed after the end of the Second World War was South Tyrol, referred to as Alto Adige (the upper valley of the Adige River) by the Italians or Südtirol by the Austrians. The area, which was given to Italy after victory in the First World War, was formerly part of the Austro-Hungarian Empire and had a German-speaking majority population.

While initially the German population had been allowed a certain degree of autonomy, with the rise to power of the Fascist regime it was deprived of its political, cultural and linguistic rights ${ }^{15}$. Their condition improved gradually in the late 1930s thanks to the political rapprochement between Fascist Italy and Nazi Germany, ${ }^{16}$ after which, in September 1943, the area was de facto annexed by German troops and included in a larger political entity called the Alpine Foreland

\footnotetext{
MUGNAINI 2017: 164.

Ibid..

SFORZA 1952: 162-163.

15 BOSELLI and SERIO 2005: 32.

16 The apex of the new climate was perhaps reached in 1939, when, after the Anschluss, an agreement signed between the two states allowed those who wished to do so to opt for German citizenship and subsequently move to the German Reich. As a consequence of the MussoliniHitler agreement, an estimated 75,000 South Tyroleans moved to the Reich. STEININGER 2008: 56.
} 
Operations Zone (Operationszone Alpenvorland) in which the native Germanspeaking population enjoyed a privileged status.

Meanwhile, in the strategic plans which being prepared in Western diplomatic circles, the problem of the future arrangement of Italy's northern border was tied to the future of Austria. Although at first both British and Americans were open to returning South Tyrol to Austria, ${ }^{17}$ a second line of thought arose in the spring of 1945 as a result of two factors: the desire to give some satisfaction to Italy, whose role in the Western bloc began to crystallize near the war's end, and the possibility that the Soviet Union would play a major role in post-war Austria. The latter hypothesis was reinforced by the creation of the interim Renner government soon after the occupation of Vienna by Soviet troops in April 1945.

However, it was the military that had the last word. In August, Marshall Harold Alexander, the Supreme Commander of the Allied Forces in the Mediterranean, requested that South Tyrol be returned to Italy, a decision approved by James Francis Byrnes, the US Secretary of State, with the provision that this would still leave the situation open for a different solution in the future.

As a consequence of this pressure by the military and due to the consideration that Italy, a country whose Western-oriented government was challenged by a large and well organized communist party, was at risk of changing its international allegiance, the United States adopted the line that the border between Italy and Austria was not to be modified except for minor alterations in favour of Austria. As Pastorelli points out, the formula adopted was virtually the same as the one for the border between Italy and France. ${ }^{18}$

The new American position, that the frontier "would be unchanged, subject to hearing any case Austria may present for minor rectification in her favour" 19 was approved at the London conference on 14 September 1945, with the support of the Soviet Union, which, on the one hand, did not want to weaken the Italian communist party by taking a position against Italy, while, on the other, it was more interested in supporting Yugoslavia in its border dispute with Italy. Another circumstance which deserves to be mentioned is Austria's weakness. Not only had the country never been at war with Italy, i.e., it was not a country on it victorious side, but its interim Renner government was not recognized by the Western powers until the autumn of 1945.

The British and the Americans had second thoughts on South Tyrol after the Austrian Communist Party was soundly defeated in the general elections in November. In a note sent to Foreign Secretary Ernest Bevin, Sir Orme Sargent

\footnotetext{
PASTORELLI 1976: 107.

18 PASTORELLI 1976: 112.

19 FRUS 1945, vol. II, 158-163.
} 
went so far as to declare that it would have been better to restore one of Italy's former colonies rather than hand them the German population of South Tyrol. ${ }^{20}$

It was too late. A decision had already been made to concede nothing more than "minor corrections" of the border to Austria, while the Soviet veto further complicated the situation, as the Americans could not afford to appear less proItalian than the Soviets.

After the Peace conference left the border between Austria and Italy unchanged, it was mainly left to the initiative of Great Britain to strengthen Italo-Austrian relations, as it was thought that "both countries, situated as they were close to the Iron Curtain, should cling together". ${ }^{21}$ The only way left to improve the relationship between them was to grant a degree of autonomy to South Tyrol together with considerable rights in the field of cultural autonomy to the German-speakers. The result, some pressure on both Austria and Italy by the British side, was the De Gasperi-Gruber agreement signed on 5 September $1946 .{ }^{22}$ Despite some initial resistance, in the end it was also appreciated by the Italian side, for it was the first agreement concluded by post-war Italy on a voluntary basis, hence setting the foundation for the country's future.

\section{The Trieste issue}

Together with South Tyrol, Istria and the Slovenian Littoral were the other former Austro-Hungarian territories which Italy obtained after the end of the First World War. The occupational regime and subsequent administration of the region did not show any respect for the Slovene and Croat populations, in contrast to the case in South Tyrol with the German-speaking minority. The invasion of Yugoslavia followed in 1941 and led to the de facto annexation of southern Slovenia and the formal union of the newly-established so-called Independent State of Croatia to the Italian crown. After the Italian capitulation in 1943, the Nazis established a special zone in the area similar to the one created in Trentino-South Tyrol, the Adriatic Littoral Operations Zone (Operationszone Adriatisches Küstenland).

Thanks to its wartime successes, the leadership of the Yugoslav Partisan movement felt entitled to claim most of the territories assigned to Italy after the First World

20 STEININGER 2008: 63.

21 STEININGER 2008: 66. Italy and Austria were in fact meant to cooperate in the event of Soviet aggression.

22 It is interesting to note that Yugoslavia closely followed developments related to South Tyrol. In a cable issued in December 1945, soon after Italy made the first autonomy concessions to the German-speaking population in the area, Smodlaka underlined that "after giving autonomy to Aosta, the project of autonomy for South Tyrol may be used as a weapon to ensure that the region remains in Italy. It may be also used as a tactical weapon in the border conflict with us". DAMSP, PA, 1945, f. 12, d. 9, 7102. 
War, including the cities of Gorizia and Trieste, which were perceived as important by the Slovenes. ${ }^{23}$ Trieste was finally liberated by 1 May 1945, one day before the arrival of Allied troops, which overlapped with Yugoslav forces in the area. ${ }^{24}$

To ensure that unilateral actions, such as the Partisan liberation of the region without the consent of the Allies, did not influence the peace talks, General Alexander persuaded the Yugoslavs to leave by various means, including the threat of force. Due to Soviet pressure, the Belgrade agreement was signed on 9 June 1945, whereby Yugoslav troops left the territories west of the Morgan line, ${ }^{25}$ which included Trieste, Gorizia and Monfalcone, relinquishing them to the joint Anglo-American military administration. ${ }^{26}$

A special inter-allied commission was sent to visit the disputed territory in order to help the peace conference make its decision on demarcation of the border, but once its decision was rendered ineffective due to four different proposed lines, ${ }^{27}$ an apparent deadlock ensued. The Soviet Union supported the territorial claims of its Yugoslav ally, while the Anglo-Americans were definitely more in favour of Italy. The impasse opened some room for manoeuvre for the French, who proposed a borderline drawn in the Istrian town of Novigrad, hence favourable to the Yugoslavs, on the assumption that by doing so they would have gained the support of the Soviet bloc in their own border problems pertaining to the Saar region. ${ }^{28}$

In May 1946, Soviet Foreign Minister Vyacheslav Molotov proposed that the entire territory be assigned to Yugoslavia, and to eventually make some concessions to Italy in the colonial field, while his American counterpart Byrnes countered with a proposal that the matter be addressed through a plebiscite, a solution that was unacceptable to the Italians, for if also applied in South Tyrol, it would have favoured Austria. ${ }^{29}$ In order to find a way out from the incompatible positions,

23 In the immediate aftermath of the fall of Italy, the Slovenian and Croatian antifascist liberation councils issued proclamations of their respective annexation of the Slovenian littoral and Istria without even waiting for approval from the central Yugoslav antifascist authority (AVNOJ). PIRJEVEC 2009: 43.

24 LLEWELLYN WOODWARD 1975: 366-369. Since some German soldiers refused to surrender to the Yugoslavs, and instead surrendered to the Anglo-Americans on the following day, some scholars - a minority - assumed that Trieste was technically liberated by the Anglo-Americans on 2 June.

25 This was the demarcation line proposed by General Morgan. It ran approximately 10 kilometres east and south of Trieste.

26 LLEWELLYN WOODWARD 1975: 371-380. The details left open in Belgrade were further addressed in the Duino Agreement signed on 20 June. 
Great Britain proposed the creation of a buffer-state. The solution, which was endorsed by Professor Mosely, an expert on communism and Eastern Europe and an authoritative member of the American team, ${ }^{30}$ gained traction during the month of June despite Yugoslav opposition.

On 3 July, it was established that the "French line" would become the border between Yugoslavia and the Free Territory of Trieste, whose northern border would run between the towns of Monfalcone and Duino, while the eastern border would be a few kilometres west of the Morgan line. The decision to form a buffer-state was already somewhat "overtaken by events". It was so reminiscent of the solutions adopted after the First World War that they were all explicitly mentioned: Stalin advocated a solution similar to the Memel Territory, while Molotov proposed a settlement inspired to the Free City of Danzig. ${ }^{31}$

Despite opposition from both the Italians and Yugoslavs, the creation of the Free Trieste Territory (FTT) was finally adopted with the signing of the peace treaty in Paris on 10 February 1947.

In the meantime, the rapid deterioration of relations between the "East" and "West" led the United States to formulate the Truman Doctrine. ${ }^{32}$ The new policy of "containment" had significant consequences for the border between Italy and Yugoslavia as it was meant to curb communist expansionism. After few months, it was clear that the FTT was already obsolete as the tiny independent state was perceived as too week to resist the political and military pressure of the Sovietbacked Yugoslavs.

The Western powers, together with the Italians as their allies, sabotaged the appointment of the governor, who was supposed to govern the FTT, in order to prevent it from becoming operational. In this case the two zones which formed the FTT, "Zone A" under Anglo-American administration and "Zone B" under Yugoslav military administration would not unite, hence direct Anglo-American governance of Trieste was prolonged. The same premises had the opposite effect on the Soviet Union. While it had been hesitant to approve the creation of the FTT, it now pushed to promote the governor's appointment as a means to remove Western troops from an area of strategic importance, the upper Adriatic. ${ }^{33}$

To make it clear that the governor would not be appointed, on 20 March 1948 the governments of France, Great Britain and the United States released a joint statement, better known as the Tripartite Declaration. According to this declaration, since it had been impossible to implement the FTT, the entire territory was

\footnotetext{
30 DE LEONARDIS 1992: 152-153; VALDEVIT 1986: 142-146.

31 PIRJEVEC 2007: 336-342; GIBIANSKII 2005: 357-690.

32 Announced during a speech delivered on 12 March 1947, the Truman Doctrine introduced the concept of "containment" as a strategy to halt the spread of communism.

33 MILLO 2011: 63.
} 
to be ceded to Italy. ${ }^{34}$ The declaration can be explained as simply a tool to support Christian Democracy, the main pro-Western political party, in the upcoming Italian elections, since it was clear that without the consent of the Soviet Union the proposal for a revision of the peace treaty could never be implemented. On the other hand, as a means to boost the performance of the Italian communist party, the Soviet Union released a statement on 17 February advocating the restoration of Italy's former colonies in a sort of trusteeship. ${ }^{35}$

As a consequence of Yugoslavia's expulsion from the Cominform ${ }^{36}$ a few months later, an event that caught Western governments by surprise, ${ }^{37}$ the issue of Trieste was no longer a bone of contention between the two blocs. While the Soviet Union never completely lost interest in it, it mainly became an internal problem of the Western alliance and an instrument to put pressure on both Italy and Yugoslavia.

After the stand-off period, the border issue was seldom raised by the US or Great Britain after 1950. As Italy's strategy was to remain faithful to the Tripartite Declaration, Yugoslavia indicated that it was amenable to some manner of partition of the territory of the FTT since mid-1949. ${ }^{38}$

While the issue was regularly exploited by Italy's government to influence electoral results, the Italian diplomats generally failed to recognize that Yugoslavia was gaining ground on the international level, until the new Italian prime minister, Giuseppe Pella, took abrupt action to halt this trend for his country in the summer of 1953 by sending troops to the border under the pretext of preventing the possible Yugoslav annexation of Zone B. ${ }^{39}$

The military confrontation which resulted between the armies of the two countries made clear that the Trieste issue had to be addressed soon for several reasons,

34 PIRJEVEC 2007: 378; VALDEVIT 1986: 192. The announcement, known as the Tripartite Declaration, was by chance issued on the same day that Tito sent a letter to Stalin concerning the crisis in their relations, which was already simmering between Yugoslavia and the Soviet Union. PASTORELLI 1987: 125.

36 Established on 5 October 1947 as a replacement for the Comintern, the Cominform was the official coordinating body of the international communist movement led by the Soviet Union. It was dissolved on 7 April 1956. JAKOVINA 2003: 232-253.

38 VALDEVIT 1986: 220.

39 In the press summary of a speech delivered by Tito on 28 August in response to a previous speech by Pella by the American agency United Press, correspondent Helene Fisher reported that "Yugoslavia had lost patience with Italy on the Trieste question and is considering changing its moderate and tolerant attitude, perhaps by annexing Zone B in reply to Italy's cold annexation of Zone A". As the threat of annexation was not present in the original Yugoslav press statement and the Italian authorities did not take any action to clarify the matter, the perceived Yugoslav annexation threat has been discarded by most scholars as simply a pretext to justify the Italian government's decision to send troops to the border (i.e., Croci 1992: 144). The Yugoslavs did, however, launch an investigation, which came to the conclusion that Mrs. Fisher had made an error. AJ 836 KMJ 1-2-a/140 no. 1777/5 of 2 September 1953. 
including the desire of the British to relieve their budget of the costs related to the occupation of Zone A, which had endured for over 8 years, and the negative impact of tense Italian-Yugoslav relations on planning for Europe's defence in case of a Soviet attack.

The pressure exerted by the Western powers resulted in negotiations held in London in two rounds - the first with Vladimir Velebit and the second with the Italian ambassador to the United Kingdom, Manlio Brosio - in the first months of $1954 .^{40}$

The outcome of the negotiations, whose aim was to reach a deal acceptable to both sides by avoiding direct contact between them, led to the Memorandum of Understanding of London signed on 5 October 1954, according to which Zone A was to be placed under Italian civilian administration, with the exception of a tiny slice of land in its southern sector which was given to Yugoslavia, together with all of Zone B, which passed from Yugoslav military to civilian administration. ${ }^{41}$

\section{The belligerent post-war period}

While, as Aleš Bebler ${ }^{42}$ pointed point out when speaking about Trieste during a meeting with the US Ambassador Riddleberger ${ }^{43}$ on 9 November 1953, it was true that for Italy "every issue could become an important sentimental issue, from Nice, Corsica, Malta and every place in the world where, for a reason or another, people speak Italian", ${ }^{44}$ there is no question that for the Italian public the issue of Trieste indeed played a special role.

It was mainly the prospect of acquiring territories on the eastern Adriatic coast that prompted the Italian political elite to enter the war in 1915 on the side of the Triple Entente, even though Italy was bound to Germany and the Austro-Hungarian Empire by the Triple Alliance. ${ }^{45} \mathrm{~A}$ vital role was also played by the lobbying activity of tens of thousands of political refugees who settled in Italy after lea-

\footnotetext{
40 The negotiations were reconstructed in detail in De Leonardis 1992: 415-466.

41 NOVAK 2011: 429-441.

42 Born in Idrija, in the Slovene Littoral, in 1907, Bebler joined the Yugoslav communist party in 1929 before moving to Paris, where he earned a doctorate in law. After fighting as a volunteer in the Spanish Civil War, he became a prominent figure in the Slovene resistance movement. After the war, he held a number of high posts, including deputy foreign minister (1952-1955) and justice in the constitutional court (1963). "Ales Bebler Dies at 74; Yugoslav Ex-Diplomat", The New York Times, 13 August 1981.

43 James Williams Riddleberger stepped in for the previous US ambassador, George Venable Allen, at the end of July 1953. He held the post until 1958.
}

44 AJ 836 I-5-c / 83 Str. pov. 529.

45 CATTARUZZA 2007: 71-84. 
ving Trentino, the Austrian Littoral and Dalmatia when the war broke out. They "contributed to the shift in Italy's territorial appetites from France to Austria". ${ }^{46}$

As a consequence of the unanticipated dissolution of the Austro-Hungarian Empire and the entry into the war by the United States, which was not bound by the Treaty of London, at the peace conference Italy was granted only some of the territories promised to it.

The failure to secure territorial acquisitions in Dalmatia or, as the Italian poet and fervid nationalist Gabriele D' Annunzio described it, the "mutilated victory", coupled with economic, social and political problems, led to the rise of fascism. A more favourable border with Yugoslavia was negotiated through the Treaty of Rapallo (1920), and later Italian pretentions to the eastern Adriatic coast were satisfied at the beginning of the Second World War, when most of Dalmatia, together with Montenegro, fell into Italian hands as the consequence of the Axis invasion of Yugoslavia in 1941. However, everything was lost with Italy's defeat in 1945 to the point that not even the future of Trieste was certain anymore.

On the other hand, the territorial claims briefly put forth by France in the final days of the war did not concern those parts of the national territory which were at the core of the national imaginary. Moreover, the United States played an important role in addressing the issue in the form of the aforementioned personal letter which President Truman sent to General De Gaulle. In fact, it was clear well before the peace conference that France, the less powerful of the Allies, was not to secure any significant corrections of its mutual border with Italy. Soon after the end of the war, however, Cold War policies helped bring the countries together. Cultural affinities apart, France and Italy were both interested in avoiding the restoration Germany as a powerful player on the European stage. As France still wanted to play the role of a big power until the early 1950 s, Italy was useful as a partner relegated to a subordinate position by the clauses of a peace treaty that limited its military and political capabilities. The turning point in Italian-French relations can be conventionally set on 20 March 1948, when the French Foreign Minister Georges Bidault, hours after announcing France's intention to form a customs union with Italy, also announced the Tripartite Declaration favouring Italy on the issue of Trieste. ${ }^{47}$

The territorial dispute with Austria over Alto Adige/Südtirol was similarly addressed by the British and Americans, whose primary aim was not to damage Italy as it began to establish its role on the Western side. While the status of Austria was precarious because the Renner government was not internationally recognized until late 1945, the issue was finally resolved to Italy's complete satisfaction, by restoring all of the disputed territory to Italy with the compliance of the Soviet

\footnotetext{
46 Ibid.

47 JANKO 1961: 207.
} 
Union, which was interested in winning Italian public sympathy in order to reinforce the Italian Communist Party's position. As a means to curb discontent from both Austria and the German-speaking minority in Alto Adige/Südtirol, the De Gasperi-Gruber Agreement became the cornerstone of successful integration of the region into the Italian state by granting wide-ranging political, cultural and fiscal autonomy to this minority. Local support for Austrian irredentism, which had previously led to the formation of the Befreiungsausschuss Südtirol (South Tyrolean Liberation Committee), dissipated. If issues related to Alto Adige/ Südtirol are still present in today Italy's public sphere, it is mainly due to media reports on the supposed economic privilege of the German-speaking population due to the prosperous local tourism industry or due to provocations by nationalist politicians on both the sides of the border, which was recently the case with the Austrian proposal to grant Austrian citizenship to the region's German-speaking. ${ }^{48}$

The colonial issue, addressed between 1949 and 1950, had for years been the object of political speculation and competition between the Italian Communist Party and the Christian Democracy party, supported respectively by the Soviet Union and the United States. In any case a clear statement in favour of the selfdetermination of Libya and Eritrea finally expressed by De Gasperi in 1949 put an end to such discussions. While it was clear that the interests of British (and to lesser extent French) foreign policy left little scope for Italian intervene, De Gasperi's move set the foundation for future friendship between Italy and the Arabic world, a friendship that would bear some fruit in the decades to come. If the issue of the former colonies is ever discussed in Italy today, it is mostly within the framework of the debate on the crimes perpetrated by Fascism in Africa, a matter that has been dealt reopened in recent years after a long period of neglect.

Unlike the disputes involving France, Austria and the former colonies, the issue of Trieste dragged on well into the 1950s before being resolved. After the Tripartite Declaration was issued in 1948, governing parties found that this issue was an easy mean to shore up political support by diverting attention away from difficult everyday conditions in the post-war years. While mass demonstrations were also held in connection to the status of the colonies and, even more so, Alto Adige/Südtirol (which was also the case in Austria), ${ }^{49}$ only those connected to the "eastern border" took the form of almost open warfare, which was the case when three days of rioting in Trieste in November 1953 left six dead bodies on the streets..$^{50}$ At the same time, the Trieste question was the subject of genuine

\footnotetext{
48 “Austria, cittadinanza ai sudtirolesi: prima polemica del governo di centrodestra con l'Europa", La Repubblica, 17 December 2017.

49 This was not the case when French troops entered in 1945, as at that time the situation in Italy was still critical and staging street protests would have been impossible.

50 BEKIĆ 1988: 559.
} 
media hype. ${ }^{51}$ To take just one example among many, Trieste was the topic of the song that won the popular Sanremo Music Festival in 1952, "Vola colomba" (literally "fly, dove", wherein the "dove", the city of Trieste, is encouraged to "come back"). Its lyrics mention the famous San Giusto Cathedral and include a few words in the Triestine dialect. ${ }^{52}$

On the one hand, the Italian public followed events pertaining to Trieste with genuine passion. On the other hand, most of the people who had left the territories ceded to Yugoslavia after the end of the Second World War ${ }^{53}$ were resettled in the area behind the newly established border, including Trieste's outskirts, with the aim of diluting the local Slovenian population. ${ }^{54}$

For these reasons, although relations between Italy and Yugoslavia steadily improved after the 1954 London Memorandum, ${ }^{55}$ the local political climate in Trieste was still so tense 20 later that in 1974 the installation of new road signs featuring the word "Slovenia" by the Yugoslavs on their side of the border was enough to prompt a campaign by the local newspaper, Il piccolo, which escalated into a full blown diplomatic crisis. ${ }^{56}$ Even after the signing of the Osimo Accords in 1975, it became evident that the atmosphere created in the border zone by, in part, the Italian national authorities persisted beyond the normalization of the relations between the two countries. Soon after the half-empty Parliament in Rome finally ratified the accords, which technically put an end to the border issue, the response of the people of Trieste rendered its full implementation impossible. ${ }^{57}$ The plan under this treaty calling for the creation of a mixed Italian-Yugoslav duty-free industrial zone in Trieste's hinterland was violently rejected by a political upwelling that wiped out the traditional political parties. A town that perceived itself as sacrificed on the altar of Rome's interests suddenly turned to a parochial populist party, the Lista per Trieste (List for Trieste) which was to rule the city

$\overline{51}$ Orecchia's book La Stampa e la Memoria. Le foibe, l'esodo e il confine orientale nelle pagine dei giornali lombardi agli albori della Repubblica (2008) provides, in its more than 400 pages, coverage of Trieste-related coverage by the press in Lombardy alone.

52 A modified version of the lyrics, sung on special occasions, was even more explicit in saying that "we were happy together, but we have been separated". It was also suggested that the young couple was employed at the local shipyard. The modified lyrics, together with a brief explanation, are quoted in: PIVATO 2007: 203-204.

53 They are mainly known in Italy as esuli, literally "the exiled". Interestingly, there is no specific name for those who left the colonies.

Cf. DOTA 2011. The diplomatic conflict, which technically involved some abstract legal issues around the "finality" of the London memorandum, has been explained as a positioning for negotiations that were supposed to happen in Osimo within a year. 
for nearly a decade with a political platform based on demands for state subsidies and hostility to Yugoslavia. ${ }^{58}$

The 1990s, a missed opportunity for a fresh start in international relations in the upper Adriatic

After memories full of hostility toward Yugoslavia and irredentism departed from the national stage, surviving for decades only in cloistered milieus such as communities of Istrian émigrés and neo-fascist circles, a real turn of the tide in relations between Italy and its eastern neighbours came as a direct consequence of the Yugoslav wars in the early 1990s. At the local Triestine level, malicious arguments arose, claiming that Italy's sovereignty over Zone B had never ceased and that, since Yugoslavia no longer existed, the Osimo Accords were no longer valid. The idea of a border revision was not taken into account by the government, which indeed recognized the independence of Slovenia and Croatia in 1992, but this hypothesis was taken far more seriously by the far-right party Movimento Sociale Italiano (Italian social movement - MSI). On the one hand, provocations which recalled D'Annunzio's Bakar mockery were staged. On the other, secret meetings took place between party officials and the Serbian leadership in August 1991 with the aim of "transforming the situation in the Balkans into a disaster so as to facilitate the return of what Italy had lost in the Second World War". ${ }^{59}$ Once the MSI, which was evolving from an openly neo-fascist into a Gaullist political party, became part of the government formed in 1994, Slovenia's entry into the European Union was vetoed by Italy, which demanded that the real estate law to be amended in order to allow foreigners (including those Italians who had left the Slovene Littoral after the Second World War) to purchase real estate in Slovenia.

While the primary effect of similar actions was to complicate relations between Italy on one side and Slovenia and Croatia on the other from the very beginning, the Yugoslav wars had another consequence. Massive coverage of the atrocities committed during the conflict fostered a resurgence of racist stereotypes in Italy against Slavic peoples, who were said to be "naturally inclined to violence". Stories related to the foibe killings, the killing of Italians by Yugoslav Partisans in the autumn of 1943 and the spring of 1945, were therefore reported by the mainstream media after forty years of neglect.

The circulation of more or less reliable accounts of the foibe killings committed during the Second World War coincided as serendipity with the crisis the Italian political system was experiencing in the same years. While the Italian Communist Party and the Christian Democracy were wiped out, respectively, by the collapse of

58 Cf. PURINI 2006.

59 PIRJEVEC 2002: 321-322. 
international communism and a major corruption scandal, the new political forces which followed them had to find a new common denominator. Antifascism, which had served this purpose until then, was no longer a viable option after the MSI had been allowed to take part in the government. The new common source of legitimacy was nationalism, of which the "forgotten story of the Italians at the eastern border" 60 was a vital ingredient. It is worth underlining that, while it is obvious that the Italian Communist Party's condemnation of the crimes of communism was a function of its post-communist transition, the condemnation of the foibe killings by the Italian left had an additional motive. Since the merits of the Italian resistance movement were increasingly challenged by the right, whose ultimate goal was to elevate those who fought alongside the Germans to the same level of honour as the partisans, the left found a way to parry a direct attack on its values by reaching a consensus with the right around the foibe killings, which had been perpetrated by foreign rather of domestic antifascists. As the propensity for violence and communism were merged into the "Slavic" stereotype forged by fascist propaganda since 1943, the left managed to dump the accusations levelled by the right onto the Yugoslavs, hence saving the virtue of the specific Italian, milder version of communism. ${ }^{61}$

The deal made between post-fascists and post-communists was formalized in Trieste in 1998 during a speech delivered by the chief of the National Alliance (Alleanza Nazionale), the new brand of the MSI, and Luciano Violante, the chairman of the Italian Chamber of Deputies under the new left-leaning government elected in 1996. After over a decade of intense publicity, however, it was in 2004 that the foibe killings became one of the de jure historical events which are of key importance for the Italian republic. In that year, in fact, the new right-leaning government of Italy approved the institution of the "Day of Remembrance" (Giorno del ricordo) "aimed at preserving and renewing the memory of the tragedy experienced by Italians and all of the victims of the foibe, of the exodus of Italians, Istrians and people from Fiume from their lands and of the complex events at the eastern border". ${ }^{2}$ The law fixed the new celebration at 10 December, anniversary of ratification of the peace treaty. It also provided generous funding to the network of associations formed by the esuli. On the other hand, the law promoted the production of books, conferences, movies and works of art to familiarize the public with events related to the end of World War II in the eastern border zone, a story which was often given a nationalist tone. ${ }^{63}$

In the 1990s and early 2000s, the stories that found their way to the mainstream were basically those that had survived oblivion in the closed circles of the esuli

\footnotetext{
DOTA 2010: 40-41.

61 Cf. TENCA MONTINI 2014; Luisa ACCATI, Renate COGOY (eds.) 2009.

62 The full text of Italian law $n^{\circ} 92 / 2004$ is available at the website www.camera.it.

63 Cf. TENCA MONTINI 2016.
} 
and splinter neo-fascist groups after the end of the war. It is then no surprise that the speech delivered by the Italian president on 10 February 2007 prompted a response from his Croatian counterpart Stjepan Mesić. Napolitano described the final phase of the war as "a wave of hatred and bloodshed that prevailed in the peace treaty of 1947 " ${ }^{64}$ Mesić replied, after observing that his Italian colleague's speech contained hints of racism, that it was "outrageous and potentially very dangerous to question the peace treaty" and that for Croatia it was "absolutely unacceptable whatsoever to question the Osimo Accords (...) which Croatia inherited as one of the successors of the former federation". ${ }^{65}$

This exchange escalated into a diplomatic incident which led some in Italy - to no avail - to demand that Croatia's accession to the European Union be put on hold. The situation was addressed in the following years by acts of appeasement such as the "concert of the three presidents" (Josipović, Napolitano and Türk) celebrated in Trieste in 2010 and a meeting between Josipović and Napolitano in Pula in 2011. Indeed, another diplomatic incident arose after the president of the European Parliament, Antonio Tajani, saluted "Italian Istria and Dalmatia" during a speech delivered in Trieste on 10 February 2019.

\section{Conclusions}

At the end of the Second World War Italy had open territorial claims against all of its neighbours except Switzerland. The disputes with France and Austria, concerning the Aosta Valley (and minor areas in the border zone) and South Tyrol respectively, were resolved soon and favourably as the Western powers - but also, to some degree, the Soviet Union - intended to support Italy, which was a potentially promising partner in the looming Cold War. This was not the case with the former colonies of Libya, Eritrea, the Italian Somaliland and Ethiopia. Great Britain in particular was interested in the territories it had held since 1943 and which were deemed strategically important. After spending some years attempting to retain some influence over its former colonies, the Italian government ultimately resolved the issue by voluntarily sacrificing its overseas dominions for the sake of future good relations with the new Arab countries, which now entered the stage of history as a result of decolonization. The case of Trieste and Venezia Giulia was different. Yugoslavia was an ally of the coalition that had won the Second World War. It had found its way to the renowned upper Adriatic port by arms and enjoyed the political support of the Soviet Union (at least to some degree) in doing

64 The full text of the speech held by President Napolitano on 10 February 2007 is available at the website http://presidenti.quirinale.it.

65 The full text of President Mesić's reply is available at the website www.index.hr, 17 February 2007. 
so. The disbandment of the antifascist alliance after the public announcement of the Truman Doctrine put the border dispute on hold and prevented the activation of the FTT, which had been set forth down in the relevant peace treaty. Occupied by Allied troops and deprived of the economic importance it had enjoyed in the old Hapsburg era, the new function of Trieste was to inflame nationalist passions in Italy in order to prevent a communist coup in the country. The expulsion of Yugoslavia from the Cominform did not change this status very much at first. In 1953, convinced that Yugoslavia's partnership with the West could be exploited by the former as a tool to enhance its position on the issue of the FTT, the more assertive attitude adopted by Pella government brought the two countries to the brink of war, after which the border issue was de facto resolved the following year in the most predictable way, as the two zones which formed the FTT were partitioned.

While situations related to the other territorial disputes quickly lost relevance after they had been addressed, this was not the case with Trieste. The conflict with Yugoslavia had lasted too long to be easily forgotten. It was bound up with the group identity of the esuli, who had been settled in large numbers in the border zone. This situation proved to be a breeding ground for the diplomatic crisis which erupted in 1974, one year before the matter of the border with Yugoslavia was formally addressed by the Osimo Accords. The bitter memory of the conflict involving Trieste and the lands lost to Yugoslavia still lingered in the 1990s, when Italy's eastern border gained relevance as a reflex of the Yugoslav wars, and in the 2000 s, when the foibe killings were used as a tool to legitimize the new political system which arose in Italy after the major political crisis of the previous decade.

Being the subject of a national memorial day, the "Giorno del ricordo" approved in 2004, and the source of the diplomatic scandal involving Croatia in 2007, the topic of the clash between Italians and the South Slavs has, in the past twenty years, been more present in the public sphere at the national level than at any other time, with the possible exception of 1954 and the release of the London Memorandum. The situation is not likely to improve in the near future, for after the issue had apparently lost some relevance after 2007, a diplomatic incident again occurred on 10 February 2019 when the President of the European Parliament, Antonio Tajani, saluted "Italian Istria and Dalmatia" while he was in Trieste. 


\section{Bibliography}

\section{Archives}

Arhiv Jugoslavije, Beograd [Archive of Yugoslavia, Belgrade] (SR AJ) - 836, I-5-c Tršćansko pitanje

Diplomatski Arhiv Ministarstva Spoljnih Poslova Republike Srbije, Beograd [Diplomatic Archive of the Ministry of Foreign Affairs of the Republic of Serbia, Belgrade] (SR DAMSP) - PA, politički arhiv (political archive)

\section{Periodicals}

Repubblica

The New York Times

\section{Websites}

www.camera.it

www.index.hr

www.presidenti.quirinale.it

\section{Literature}

ACCATI, Luisa and COGOY, Renate (eds.). 2009. Fojbe: Primer psihopatološke recepcije zgodovine. Ljubljana: Krtina.

BEKIĆ, Darko. 1988. Jugoslavija u hladnom ratu-odnosi sa velikim silama 1945-1955. Zagreb: Globus.

BOSELLI, Gabriele, SERIO, Nicola. 2005. Fondazioni culturali delle riforme scolastiche. Rome: Armando.

CATTARUZZA, Marina. 2007. L'Italia e il confine orientale. Bologna: Il Mulino.

CROCI, Osvaldo. 1992. "The USA, Yugoslavia and the Question of Trieste: The American Policy Reversal of October 1953. In: Eastern Europe and the West, Morrison, John, (ed.), 140-70. New York: St Martin's Press.

D'AMELIO, Diego. 2013. Il dibattito pubblico sul trattato di Osimo fra ragion di Stato e protesta locale, Qualestoria 2: 83-107.

DE CASTRO, Diego. 1981. La questione di Trieste, La questione di Trieste. L'azione politica e diplomatica italiana dal 1943 al 1954. Vol. 1. Trieste: Lint.

DE LEONARDIS, Massimo. 1992. La "diplomazia atlantica” e la soluzione del problema di Trieste (1952-1954). Naples: Edizioni scientifiche italiane.

DOTA, Franko, 2011. U obrani granice: jugoslavensko-talijanski granični spor u proljeće 1974. godine, Historijski zbornik 64: 515-548.

DOTA, Franko. 2010. Zaraćeno poraće. Konfliktni i konkurentski narativi o stradanju $i$ iseljavanju Talijana Istre. Zagreb: Srednja Europa.

Foreign relations of the United States, Diplomatic Papers 1945, VOL. IV Europe. 
FRANÇOIS-PONCET, André. 2009. A Palazzo Farnese. Memorie di un ambasciatore a Roma 1938-1940. Firenze: Le Lettere.

HARRIS, Charles Reginald Schiller. 1957. Allied Military Administration of Italy 19431945. London: Her Majesty's Stationery Office.

GIBIANSKII, Leonid. 2005. The Trieste issue and the Soviet Union in the 1940s. In: Vojna in mir na Primorskem. Od kapitulacije Italije leta 1943 do Londonskega memoranduma leta 1954, Jože Pirjevec, Gorazd Bajc, Borut Klabjan (eds.), 357-390. Koper: Založba Annales.

JAKOVINA, Tvrtko. 2003. Američki komunistički saveznik. Zagreb: Profil/Srednja Europa.

JANKO, Jeri. 1961. Tržasko vprasanje po drugi svetovni vojni, Tri faze diplomatskega boja. Ljubljana: Cankarjeva Zalozba.

LLEWELLYN WOODWARD, Ernest. 1975. British Foreign Policy in the Second World War. London: Her Majesty's Stationery Office.

MILLO, Anna. 2011. La difficile intesa, Roma e Trieste nella Questione Giuliana 19441954. Trieste: Edizioni Italo Svevo.

MONZALI, Luciano. 2015. Pietro Quaroni e la questione delle colonie africane dell'Italia: 1945-1949, Nuova rivista storica 2/99: 459-498.

MUGNAINI, Marco. 2017. 70 anni di storia dell'ONU, 60 anni di Italia all'ONU. Milan: FrancoAngeli.

NOVAK, Bogdan. 2011. Trieste 1941-1954. Milano: Mursia.

ORECCHIA, Antonio Maria. 2008. La stampa e la memoria: le foibe, l'esodo e il confine orientale nelle pagine dei giornali lombardi agli albori della Repubblica. Varese: Insubria University Press.

PASTORELLI, Pietro. 2009. Il ritorno dell'Italia nell'Occidente. Racconto della politica estera italiana dal 15 settembre 1947 al 21 novembre 1949. Milan: LED.

PASTORELLI, Pietro. 1987. La crisi del marzo 1948 nei rapporti italo-americani. In: La politica estera italiana del dopoguerra. Bologna: il Mulino.

PASTORELLI, Pietro. 1976. La questione del confine italo-austriaco alla Conferenza di pace / Das italienischösterreichische Grenzproblem auf der Pariser Friedenskonferenz>. In: L'accordo Degasperi-Gruber del 5 settembre 1946, Umberto Corsini (ed.), 103-136. Trento: Regione Trentino - Alto Adige.

PIRJEVEC, Jože. 2009. Foibe, una storia d'Italia. Turin: Einaudi.

PIRJEVEC, Jože. 2007. 'Trst je naš!'. Boj Slovencev za morje (1848-1954). Ljubljana: Nova revija.

PIRJEVEC, Jože. 2002. Le guerre Jugoslave 1991-1999. Turin: Einaudi.

PIVATO, Stefano. 2007. Bella Ciao. Canto e politica nella storia d'Italia. Bari: Laterza.

PURINI, Piero. 2014. Metamorfosi etniche. I cambiamenti di popolazione a Trieste, Gorizia, Fiume e in Istria 1914-1975. Udine: Kappa Vu.

PURINI, Piero. 2006. Una conseguenza degli accordi di Osimo: la nascita della Lista per Trieste. In: Osimska meja. Jugoslovansko-italijanska pogajanja in razmejitev leta, Jože Pirjevec, Borut Klabjan, Gorazd Bajc (eds.), 195-208. Koper: Založba Annales. 
RAINERO, Romain. 2011. L'opinion publique italienne et l'annexion de La Brigue et de Tende à la France, Cahiers de la Méditerranée 62: 215-232.

ROLANDI, Francesca. 2015. Con ventiquattromila baci. L'influenza della cultura di massa italiana in Jugoslavia (1955-1965). Bologna: Bononia University Press.

SFORZA, Carlo. 1952. Cinque anni a Palazzo Chigi. La politica estera italiana dal 1947 al 1951. Rome: Atlante.

STEININGER, Rolf. 2008. Austria, Germany, and the Cold War: From Anschluss to State Treaty, 1938-1955. New York: Berghahn Books.

TENCA MONTINI, Federico. 2016. Politika sjećanja za postideološka vremena: slučaj Italije, Politička Misao 3/53: 7-25.

TENCA MONTINI, Federico. 2014. Fenomenologia di un martirologio mediatico. Le foibe nella rappresentazione pubblica dagli anni Novanta ad oggi. Udine: Kappa Vu.

TOKAREV, Sergej Aleksandrović. 1995. Trieste 1946-1947 nel diario di un componente sovietico della commissione per i confini italo-jugoslavi. Udine: Del Bianco.

VALDEVIT, Giampaolo. 1986. La questione di Trieste 1941-1954, politica internazionale e contesto locale. Milano: Franco Angeli.

VIGNOLI, Giulio. 2008. Rettifiche confinarie, mutilazioni territoriali, cessioni coloniali: da Briga a Fiume, da Asmara a Rodi, In: La sconfitta rimossa: 1947-2007. A sessant'anni dal Trattato di pace, Piero Delbello, Roberto Spazzali (eds.), 17-22. Trieste: Edizioni Italo Svevo.

VOLK, Sandi. 2004. Esuli a Trieste. Bonifica nazionale e rafforzamento dell'italianità al confine orientale. Udine: Kappa $\mathrm{Vu}$. 


\section{GORUĆA GRANICA. Komaprativna studija tršćanskog pitanja i drugih teritorijalnih problema s kojima se Italija suočila nakon poraza u Drugome svjetskom ratu}

U članku se objašnjava zašto je, od svih teritorijalnih pitanja koja je Italija imala sa zemljama u susjedstvu na kraju Drugog svjetskog rata, tršćansko jedino koje još uvijek utječe na talijansko javno mnijenje i politiku. U prvom se dijelu članka ukratko opisuje teritorijalni spor koji je Italija imala s Francuskom, talijanskim bivšim kolonijama, Austrijom i Jugoslavijom. Ta su pitanja promatrana u glavnim crtama radi konciznosti, s fokusom na uzajamni utjecaj koji su međusobno imali jedna na druge $u$ fazi kad je početak hladnog rata utjecao na sve njih. U drugom se dijelu članka objašnjava zašto je tršćansko pitanje tako posebno i zašto još uvijek igra važnu ulogu u talijanskoj nacionalnoj svijesti. Članak se temelji na radovima talijanske, hrvatske i slovenske historiografije, a kako bi se bolje objasnilo određene detalje, korišteno je nekoliko dokumenata iz Kancelarije Maršala Jugoslavije (Fond 836 - Arhiv Jugoslavije) te Političkog arhiva Ministarstva vanjskih poslova Republike Srbije (PA - DAMSP).

Ključne riječi: Pariška mirovna konferencija (1947), Hladni rat, Tršćansko pitanje, Južni Tirol, bivše talijanske kolonije

Key words: Paris Peace Conference (1947), Cold War, Trieste crisis, South Tyrol, former Italian colonies

Federico Tenca Montini Università degli Studi di Teramo Facoltà di scienze della comunicazione Via Renato Balzarini, 1, 64100 Teramo (Italy) federicotenca@gmail.com 


\section{FILOZOFSKI FAKULTET SVEUČILIŠTA U ZAGREBU \\ ZAVOD ZA HRVATSKU POVIJEST \\ INSTITUTE OF CROATIAN HISTORY \\ INSTITUT FÜR KROATISCHE GESCHICHTE}

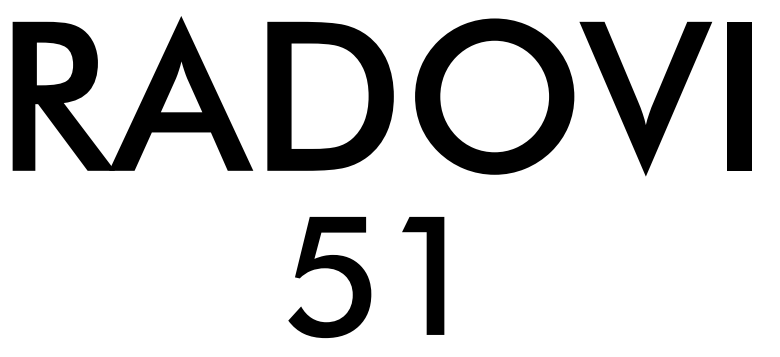

BROJ 2

ZAVOD ZA HRVATSKU POVIJEST

FILOZOFSKOGA FAKULTETA SVEUČILIŠTA U ZAGREBU

\section{FF press}

ZAGREB 2019. 


\title{
RADOVI ZAVODA ZA HRVATSKU POVIJEST FILOZOFSKOGA FAKULTETA SVEUČILIŠTA U ZAGREBU
}

\author{
Knjiga 51, broj 2
}

\author{
Izdavač / Publisher \\ Zavod za hrvatsku povijest \\ Filozofskoga fakulteta Sveučilišta u Zagrebu \\ FF-press \\ Za izdavača / For Publisher \\ Vesna Vlahović Štetić \\ Glavni urednik / Editor-in-Chief \\ Inga Vilogorac Brčić \\ Izvršni urednik / Executive Editor \\ Kornelija Jurin Starčević \\ Uredništvo / Editorial Board
}

Jasmina Osterman (stara povijest/ancient history), Trpimir Vedriš (srednji vijek/medieval history), Hrvoje Petrić (rani novi vijek/early modern history), Željko Holjevac (moderna povijest/ modern history), Tvrtko Jakovina (suvremena povijest/contemporary history), Silvija Pisk

(mikrohistorija i zavičajna povijest/microhistory and local history),

Zrinka Blažević (teorija i metodologija povijesti/theory and methodology of history)

Međunarodno uredničko vijeće / International Editorial Council

Denis Alimov (Sankt Peterburg), Živko Andrijašević (Nikšić), Csaba Békés (Budapest), Rajko

Bratož (Ljubljana), Svetlozar Eldarov (Sofija), Toni Filiposki (Skopje), Aleksandar Fotić

(Beograd), Vladan Gavrilović (Novi Sad), Alojz Ivanišević (Wien),

Egidio Ivetić (Padova), Husnija Kamberović (Sarajevo), Karl Kaser (Graz),

Irina Ognyanova (Sofija), Géza Pálffy (Budapest), Ioan-Aurel Pop (Cluj),

Nade Proeva (Skopje), Alexios Savvides (Kalamata), Vlada Stanković (Beograd),

Ludwig Steindorff (Kiel), Peter Štih (Ljubljana)

Izvršni urednik za tuzemnu i inozemnu razmjenu /

Executive Editor for Publications Exchange

Martin Previšić

Tajnik uredništva / Editorial Board Assistant

Dejan Zadro

Adresa uredništva/Editorial Board address

Zavod za hrvatsku povijest, Filozofski fakultet Zagreb, Ivana Lučića 3, HR-10 000, Zagreb Tel. ++385(0)1 6120191

Časopis izlazi jedanput godišnje / The Journal is published once a year

Časopis je u digitalnom obliku dostupan na / The Journal in digital form is accessible at Portal znanstvenih časopisa Republike Hrvatske „Hrčak“ http://hrcak.srce.hr/radovi-zhp

Financijska potpora za tisak časopisa / The Journal is published with the support by Ministarstvo znanosti, obrazovanja i športa Republike Hrvatske

Časopis je indeksiran u sljedećim bazama / The Journal is indexed in the following databases: Directory of Open Access Journals, EBSCO, SCOPUS, ERIH PLUS, Emerging Sources Citation Index - Web of Science 


\title{
Naslovna stranica / Title page by Marko Maraković
}

\section{Grafičko oblikovanje i računalni slog / Graphic design and layout Marko Maraković}

\author{
Lektura / Language editors \\ Samanta Paronić (hrvatski / Croatian) \\ Edward Bosnar (engleski / English)
}

Tisak / Printed by

Tiskara Zelina, Sv. Ivan Zelina

Naklada / Issued

200 primjeraka / 200 copies

Ilustracija na naslovnici

Muza Klio (Alexander S. Murray, Manual of Mythology, London 1898)

Časopis je u digitalnom obliku dostupan na Portalu znanstvenih časopisa Republike Hrvatske ,Hrčak“ http://hrcak.srce.hr/radovi-zhp

The Journal is accessible in digital form at the Hrcak - Portal of scientific journals of Croatia http://hrcak.srce.hr/radovi-zhp 